\title{
Infestation and natural parasitism of aphids in single and mixed pastures of black oats and ryegrass
}

\author{
Vinícius Soares Sturza1, Sônia Poncio², Aline Bosak dos Santos² \& Marcelo Lopes-da-Silva ${ }^{3}$
}

\author{
${ }^{1}$ Programa de Pós-graduação em Agronomia, Universidade Federal de Santa Maria, Avenida Roraima, Bairro Camobi, 1000, $97105-900$ Santa \\ Maria-RS, Brasil.vsturza27@yahoo.com.br \\ ${ }^{2}$ Programa de Pós-graduação em Agrobiologia, Universidade Federal de Santa Maria, Avenida Roraima, Bairro Camobi, 1000, $97105-900$ Santa \\ Maria-RS, Brasil.soniaponcio@yahoo.com.br; aline.bosak@yahoo.com.br \\ ${ }^{3}$ Embrapa Recursos Genéticos e Biotecnologia, Parque Estação Biológica, Avenida W5 Norte (final), 70770-900 Brasília-DF, Brazil. \\ msilva@cenargen.embrapa.br
}

\begin{abstract}
Infestation and natural parasitism of aphids in single and mixed pastures of black oats and ryegrass. Some species of aphids are major pests on cereal crops and grass pastures. Usually these pests are not adequately controlled in pasture lands that become sources of aphid infestations to cereal crops. The dynamics of aphids and the incidence of natural enemies are less known in pasture systems than in cereal fields. The objective of this work was to assess the aphid infestation and natural aphid parasitism in different pasture composition. Three hypotheses were tested: 1- the aphid species composition in pastures may vary according to the cereal species in the field; 2- the mixture of two plant species can modify the amount and diversity of aphids; 3 - the plant species composition of pasture fields influences the parasitism of aphids. Empirical data were obtained from three Poaceae fields: black oats (Avena strigosa L.), ryegrass (Lolium multiflorum L.), and a mixed field of black oats and ryegrass. The most abundant aphid species was Rhopalosiphum padi followed by Sitobion avenae. Plant species composition increases the amount and the parasitism rates of aphids. The mixture of heavily infested black oats with a poorly infested ryegrass resulted in reduction of aphid infestation in comparison with heavily-infested single plant species field. This is possible because the conditions are favorable for the development of parasitoid populations. Aphidius colemani was the main parasitoid found in these areas.
\end{abstract}

KEYWORDS. Aphididae; Avena strigosa L.; cereal crops; Lolium multiflorum L; natural parasitism.

RESUMO. Infestação e parasitismo natural de afídeos em pastagens com espécie única ou mistura de aveia preta e azevém. Algumas espécies de pulgões são importantes pragas de cereais, atacando também pastagens de gramíneas. Normalmente, essas pragas não são controladas nas pastagens e podem tornar-se fontes de infestação dos afídeos para os cereais cultivados. A dinâmica dos afídeos e de seus inimigos naturais é pouco conhecida em sistemas de pastagem. O objetivo deste trabalho foi avaliar a infestação de pulgões e seu parasitismo natural em áreas com diferentes composições de pastagens. Três hipóteses foram testadas: 1 - a composição de espécies de afídeos em pastagens pode variar de acordo com as espécies de plantas na área; 2 - a mistura de duas espécies de plantas pode modificar a quantidade e diversidade de afídeos; 3 - a composição de espécies de plantas da pastagem influencia no parasitismo de afídeos. Os dados empíricos foram obtidos a partir de três áreas avaliadas: um campo de aveia preta (Avena strigosa L.), um campo de azevém (Lolium multiflorum L.) e um campo misto de aveia preta e azevém. A espécie de afídeo mais abundante foi Rhopalosiphum padi, seguida por Sitobion avenae. A mistura de espécies de plantas aumenta a quantidade e as taxas de parasitismo de afídeos. A combinação de plantas altamente infestadas de aveia preta com poucas plantas de azevém infestadas resultou na redução da infestação de pulgões, em comparação com um campo altamente infestado de uma única espécie de planta. Isto deve-se às condições favoráveis para o desenvolvimento das populações de parasitoides. Aphidius colemani foi o principal parasitoide encontrado nessas áreas.

PALAVRAS-CHAVE. Aphididae; Avena strigosa L.; cultura de cereais; Lolium multiflorum L.; parasitismo natural.

Grazing lands in general represents low diversity systems; however, diversity can be increased by adding one or more foraging species. The mixture of plant species in pastures results in reduction of invasive organisms (Sanderson et al. 2007) and such strategy can be useful for pest management purposes (Muyheko et al. 2003). Usually, pasture pests are not suitably controlled and can be a source of pests to other field crops; but management of plant diversity can reduce pest problems (ARS-USDA 2011).

In Southern Brazil, black oats (Avena strigosa L.) and ryegrass (Lolium multiflorum L.) (Poaceae) have been used as alternative food supply for cattle feeding during the winter months (Aguinaga et al. 2008). Many insect pests are associated with these two gramineous species; several aphid species are among them (Blackman \& Eastop 2000). Aphids damage plants by sucking sap, injecting toxic substance, and acting as virus vectors.

Five aphid species (Hemiptera, Aphididae) are commonly found on oats in Brazil: Metopolophium dirhodum (Walker, 1849), Sitobion avenae (Fabricius, 1775), Schizaphis graminum (Rondani, 1852), Rhopalosiphum padi (Linnaeus, 1758), and Rhopalosiphum maidis (Fitch, 1856) (Celis et al. 1997; Ronquin et al. 2004). Mixture of foraging species, such as black oats and ryegrass are commonly used by farmers because they can extend the grazing period in the field (Luczyszyn \& Rossi Júnior 2007) and improve the yield of dry matter for grazing. 
Grasslands can be a primary source of aphids migrating to other cereal crops, such as wheat (Triticum aestivum L.), oats (Avena spp.) and barley (Hordeum vulgare L.). On the other hand, pastures can also be a source of natural enemies of aphids. It is not known how the mixture of grasses in pastures can affect the composition and diversity of aphid species and aphid parasitoids in the field. This knowledge is essential to understand the dynamics of aphid outbreaks in cereal crops. The objective of this work was to assess the aphid infestation and natural parasitism on aphids in pasture fields with different plant species composition. Three hypotheses were tested based on the results of aphid and parasitoid surveys: 1- The aphid species composition in pastures can be different according to the composition of plant species (black oats and ryegrass); 2 - the mixture of two plant species (black oats and ryegrass) can modify the amount and diversity of aphids in comparison with a field of single plant species; 3- the plant species composition of a pasture has an effect on the parasitism rate of aphids.

\section{MATERIAL AND METHODS}

The survey of aphids and parasitoids was conducted in a rural area of São Vicente do Sul, county in mid-western of Rio Grande do Sul State, in Southeastern Brazil (2942' 0"S latitude, 54 $39^{\circ}$ ' 5"W longitude and $121 \mathrm{~m}$ above sea level). One of the fields was a $1,050 \mathrm{~m}^{2}$ area of black oats (BO), another was a $1,750 \mathrm{~m}^{2}$ area of ryegrass $(\mathrm{RG})$, and the third field was a $1,050 \mathrm{~m}^{2}$ area of a mixture of black oats and ryegrass $(\mathrm{BO}+\mathrm{RG})$. The distance between $\mathrm{BO}$ and $\mathrm{RG}$ was $20 \mathrm{~m}$, and from these to $\mathrm{BO}+\mathrm{RG}$ the distance was $230 \mathrm{~m}$.

The soil preparation was conventional with manual sowing, using $20 \mathrm{~kg}$ of seeds in the BO field, $12 \mathrm{~kg}$ in the RG and $18 \mathrm{~kg}$ in the $\mathrm{BO}+\mathrm{RG}$ ( $8 \mathrm{~kg}$ of black oats seeds $+10 \mathrm{~kg}$ of ryegrass). These fields were bordered by sugarcane field to the west, wooded area to the north and native pastures in the southern, eastern sides and between the experimental areas.

The insect survey was carried out six times with sevenday intervals, except during rainfall period, when an additional time of seven days was required for a new survey. Surveys were done in the winter 2009: July $24^{\text {th }}(1)$, August $2^{\text {nd }}(2)$, August $15^{\text {th }}(3)$, August $23^{\text {rd }}(4)$, August $29^{\text {th }}(5)$ and September $6^{\text {th }}(6)$.

Six collection points were randomly chosen within each field, each one measuring $0.24 \mathrm{~m}^{2}(0.6 \mathrm{~m} \mathrm{x} 0.4 \mathrm{~m})$ and bounded by a square wooden frame. All nymphs and adults of aphids collected were transferred to plastic bags with leaves for transportation to the laboratory. Aphids killed by parasitism were counted separately, using the same survey plan, but in this case only mummies (aphid carcasses left by parasitoids) were counted, but not identified. We called this variable "parasitism observed in field" $\left(\mathrm{P}_{\mathrm{f}}\right)$.

In laboratory, the aphids were identified, counted and kept isolated in controlled environmental conditions $\left(25 \pm 1^{\circ} \mathrm{C}\right.$, $60 \pm 10 \%$ r.h.) for parasitoid emergence. Parasitoids emerged were preserved in vials with $70 \%$ ethanol, and mounted on slides for identification by specialists. We called this "parasitism observed in laboratory" $\left(\mathrm{P}_{1}\right)$.

After the logarithmical transformation, the ANOVA F test was performed in order to detect significant differences between the average number of aphids and aphid carcasses in the fields (Statistical Analysis System, version 8.2 - SAS2001). Chi-square tests with Yates correction for continuity were also performed to compare parasitism and aphid species proportion in each field plot.

\section{RESULTS AND DISCUSSION}

The number of aphids was higher in the $\mathrm{BO}$ field, followed by $\mathrm{BO}+\mathrm{RG}$ and $\mathrm{RG}$. Despite the fact that $\mathrm{BO}$ presented higher infestation levels in all surveys, it was not statistically different from BO+RG (Table I).

The aphid species found were Rhopalosiphum padi (Linnaeus, 1758), Rhopalosiphum maidis (Fitch, 1856), Metopolophium dirhodum (Walker, 1849), Sitobion avenae (Fabricius, 1775) and Schizaphis graminum (Rondani, 1852) (Hemiptera, Aphididae). All species were collected in the $\mathrm{BO}+\mathrm{RG}$ field. S. graminum was not collected in RG, while $M$. dirhodum was collected only in the $\mathrm{BO}+\mathrm{RG}$ field. The low density of $M$. dirhodum was not appropriate for analysis of field type/aphid species associations. The density of aphids reduced in the last samplings (Fig. 1D). In all collections, the aphid population in the RG field was significantly lower than in the other two fields (Table I, Fig. 1A-D).

Table I. Mean number of aphids per sampling point (1-6) collected in black oats (BO), Avena strigosa L., ryegrass (RG), Lolium multiflorum L., and mixed BO+RG fields. São Vicente do Sul, RS, Brazil, winter 2009.

\begin{tabular}{lcccccc}
\hline Sampling point & 1 & 2 & 3 & 4 & 5 & 6 \\
\hline Crop & $7.5 \mathrm{Aa}^{*}$ & $12.1 \mathrm{Aa}$ & $13.8 \mathrm{Aa}$ & $11.1 \mathrm{Aa}$ & $4.3 \mathrm{Aa}$ & $1.4 \mathrm{Aa}$ \\
\hline $\mathrm{BO}$ & $9.2 \mathrm{Aa}$ & $10.1 \mathrm{Aa}$ & $7 \mathrm{Aa}$ & $3.4 \mathrm{Aa}$ & $1.5 \mathrm{Aa}$ & $0 \mathrm{Aa}$ \\
$\mathrm{BO}+\mathrm{RG}$ & $0 \mathrm{Ba}$ & $1.5 \mathrm{Ba}$ & $3 \mathrm{Ba}$ & $2 \mathrm{Ba}$ & $1 \mathrm{Ba}$ & $0 \mathrm{Ba}$ \\
$\mathrm{RG}$ & 35.65 & & & & & \\
$\mathrm{CV}(\%)$ & 0.0001 & & & & & \\
$\mathrm{P}^{* *}$ treatment & & & & & \\
$\mathrm{P}^{* * *}$ survey & 0.0002 & & & & &
\end{tabular}

*Means followed by different capital letters, in columns, and lowercase letters, in rows, show significant difference $(\mathrm{P}<0.05) . \mathrm{CV}=$ coefficient of variation; $* * \mathrm{P}=$ probability of error for treatment; $* * * \mathrm{P}=$ probability of error for survey date.

The bird-cherry oat aphid, $R$. padi, was the most abundant aphid in BO and BO+RG fields. In the RG fields, $S$. avenae was as abundant as $R$. padi. The proportion of $R$. padi was higher in the mixed field $(\mathrm{df}=1$, chi-square $=14.97$ $\mathrm{p}=0.0001$ ) in comparison with BO field (Fig. 1).

The $\mathrm{P}_{\mathrm{f}}$ (number of carcasses) found in the fields of $\mathrm{BO}$ and $\mathrm{BO}+\mathrm{RG}$ were higher than in the ryegrass field, for all surveyed dates. However, in proportional terms, meaning Pf/ aphids collected, the $\mathrm{P}_{\mathrm{f}}$ was similar in the three fields (Table II). 

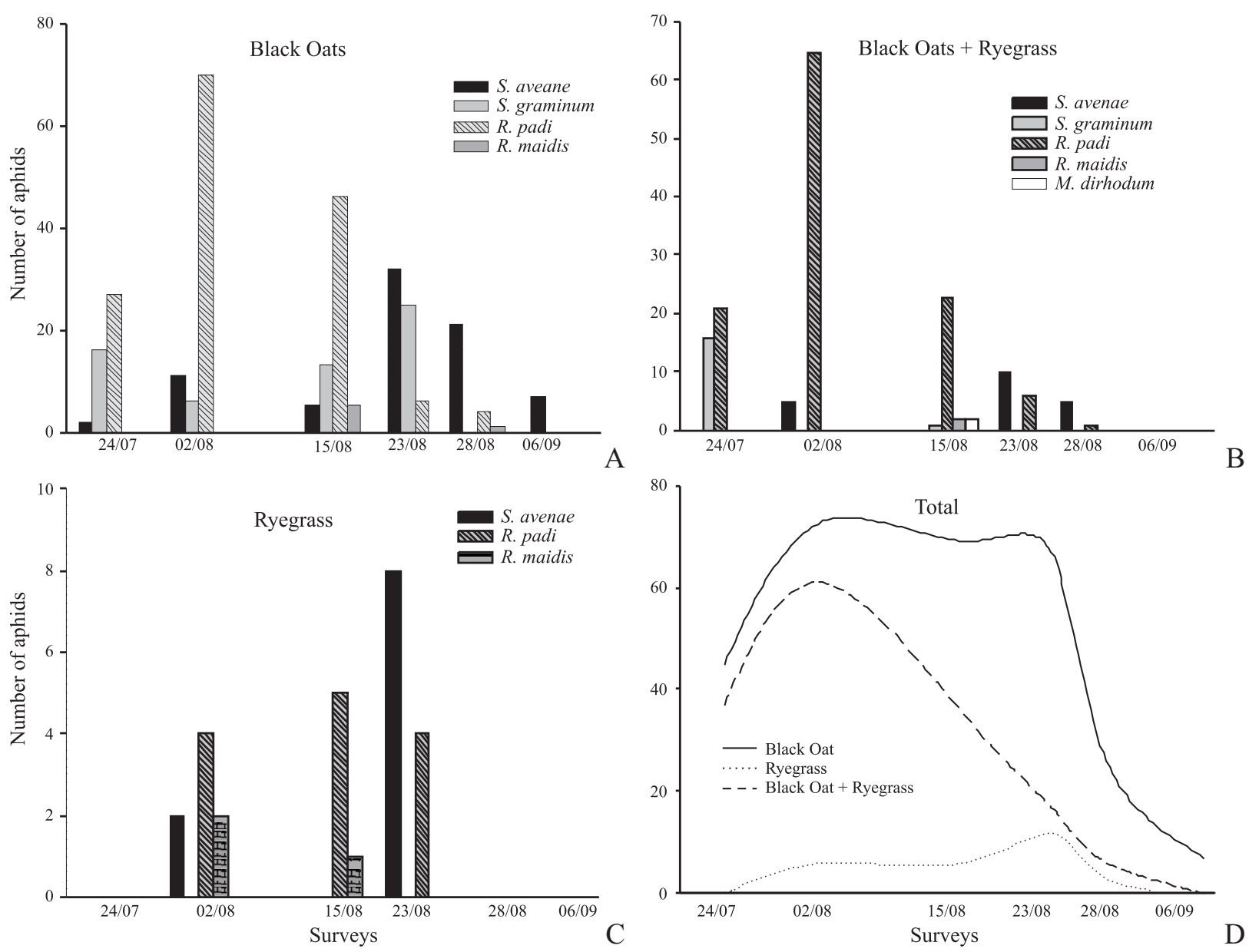

Fig. 1. Aphid species and number of individuals collected per species in (A) black oats (BO), Avena strigosa L., (B) mixture of BO+RG fields, and (C) ryegrass (RG), Lolium multiflorum L., in six survey dates. (D) Total of aphids collected per field on six sample dates. São Vicente do Sul, RS State, Brazil, winter 2009

Table II. Parasitism in the Field (Pf) - Mean number of aphid mummies per sampling point (1-6) on black oats (BO), Avena strigosa, ryegrass (RG), Lolium multiflorum, and $\mathrm{BO}+\mathrm{RG}$ fields, on different survey dates. São Vicente do Sul, RS, Brazil, winter 2009.

\begin{tabular}{lccccccc}
\hline Survey & 1 & 2 & 3 & 4 & 5 & 6 \\
\hline Crop & \multicolumn{7}{c}{ Mean number of mummies } \\
\hline BO & $2 \mathrm{Aa}^{*}$ & $1 \mathrm{Aa}$ & $5 \mathrm{Aa}$ & $2.5 \mathrm{Aa}$ & $6.5 \mathrm{Aa}$ & $1.2 \mathrm{Aa}$ \\
$\mathrm{BO}+\mathrm{RG}$ & $3.5 \mathrm{Aa}$ & $1 \mathrm{Aa}$ & $7 \mathrm{Aa}$ & $4 \mathrm{Aa}$ & $1.3 \mathrm{Aa}$ & $1 \mathrm{Aa}$ \\
$\mathrm{RG}$ & $0 \mathrm{Aa}$ & $1 \mathrm{Aa}$ & $1.5 \mathrm{Aa}$ & $2.7 \mathrm{Aa}$ & $0 \mathrm{Aa}$ & $0 \mathrm{Aa}$
\end{tabular}

CV (\%) $\quad 32.89$

$\mathrm{P} * *$ treatment $\quad 0.0001$

$\mathrm{P} * * *$ survey $\quad 0.0466$

*Means followed by different capital letters, in columns, and lowercase letters, in rows, show significant difference by Test $\mathrm{F}(\mathrm{P}<05)$. $\mathrm{CV}=$ coefficient of variation; $* * \mathrm{P}=$ probability of error for treatment; $* * * \mathrm{P}=$ probability of error for survey date.

The $\mathrm{P}_{1}$ was lower in $\mathrm{BO}$ than $\mathrm{BO}+\mathrm{RG}$ in almost all the surveys and the parasitism rate was greater in the mixed field $\left(\chi^{2}=4.11, \mathrm{df}=1, \mathrm{p}=0.0426 ; \chi^{2}=8.47, \mathrm{df}=1, \mathrm{p}=0.0036 ;\right.$ $\left.\chi^{2}=8.77, \mathrm{df}=1, \mathrm{p}=0.0031\right)($ Fig. $2 \mathrm{~A}-\mathrm{C})$. Parasitism reached its population peak in the third survey for $\mathrm{BO}$ and $\mathrm{BO}+\mathrm{RG}$.
The most commonly parasitoid species was Aphidius colemani Viereck, 1912 (Hymenoptera, Braconidae), but its proportion was not significantly different between $\mathrm{BO}+\mathrm{RG}$ and BO fields $\left(\chi^{2}=0.02, \mathrm{df}=1, \mathrm{p}=0.89\right)$ (Table III).

Table III. Parasitism observed in laboratory (Pl). Parasitoid species emerged from aphids collected from fields of black oats (BO), Avena strigosa L., ryegrass (RG), Lolium multiflorum L., and mixture of BO+RG. São Vicente do Sul, RS, Brazil, winter 2009.

\begin{tabular}{lrcc}
\hline \multirow{2}{*}{ Parasitoid } & \multicolumn{3}{c}{ Field } \\
\cline { 2 - 4 } & BO & RG & BO + RG \\
\hline Aphidius colemani & 37 & 10 & 52 \\
Aphidius sp. (except A. colemani) & 7 & 1 & 11 \\
Diaretiella rapae & 4 & - & 1 \\
\hline Total & 48 & 11 & 64 \\
\hline
\end{tabular}

There are many factors that affect aphid colonization and settlement in their host-plants. Some are: natural chemical attractants (Vos \& Jander 2010), chemical compounds eaten by aphids (Powell et al. 2006), parasitism (Östmann 2004) or host symbionts (Meister et al. 2006). Black oats have been 

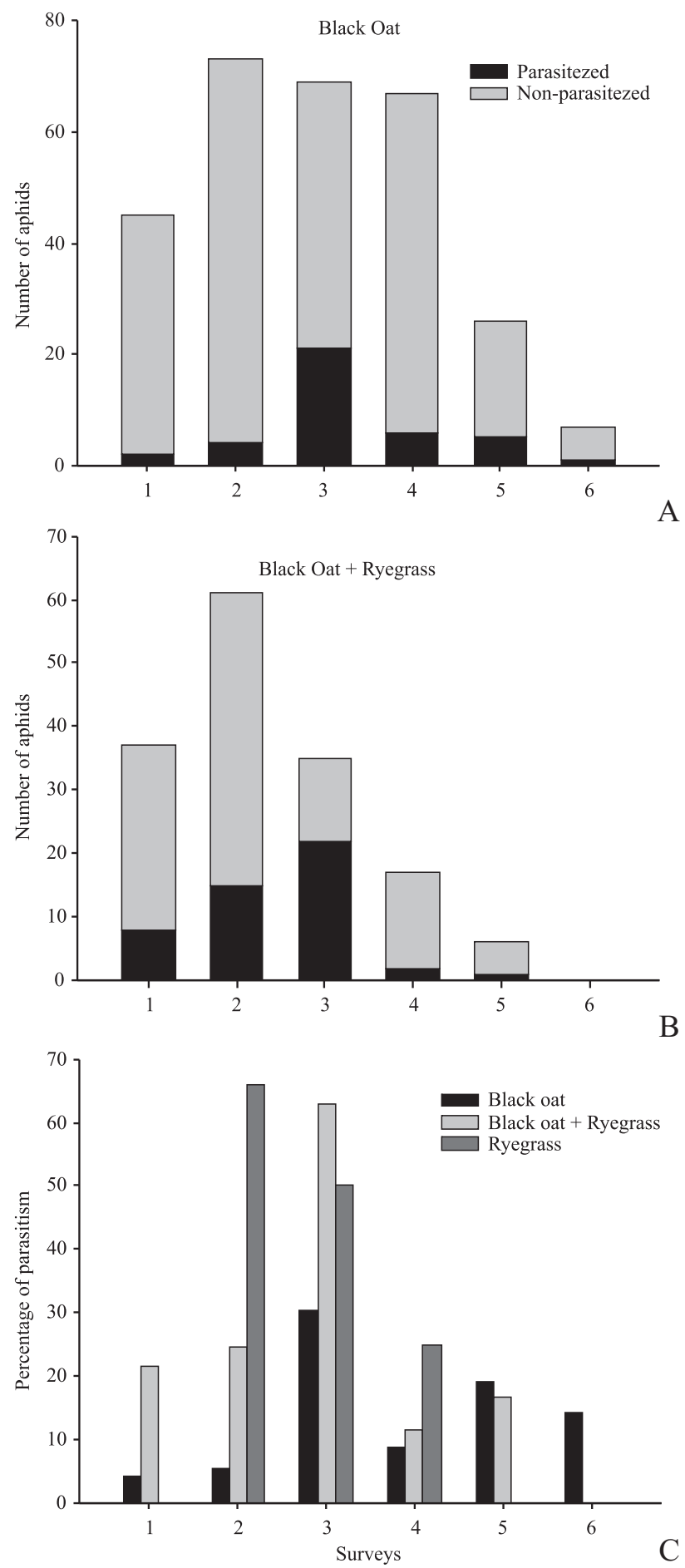

Fig. 2. Parasitism observed in laboratory $\left(\mathrm{P}_{1}\right)$. Number of parasitized and non-parasitized aphids in (A) black oats (BO) Avena strigosa L., and (B) in mixture of $\mathrm{BO}$ and ryegrass (RG), Lolium multiflorum L., fields. (C) Percentage of parasitism in $\mathrm{BO}$ and mixture of $\mathrm{BO}+\mathrm{RG}$ fields. São Vicente do Sul, RS State, Brazil, winter 2009.

reported as a suitable food source for aphids (Lopes-da-Silva \& Vieira 2007; 2010). According to our results, ryegrass was an unsuitable host for aphid colonization. This report is the first finding of differences of aphid colonization in ryegrass and other cultivated Poaceae. Host plants can select specific aphid genotypes or species. Many grasses contain hydroxamic acids, a defense mechanism against aphid attacks (Givovich $\&$ Niemeyer 1994). High levels of these compounds are found in wheat and maize, but they are absent in oats and ryegrass (Figueroa et al. 2002). In terms of evaluation of aphid fitness in 13 grasses, Fraser \& Grimer (1999) found that Lolium perenne L. was intermediary in terms of aphid development. However, L. perenne is considered an unsuitable host for aphids because of its association with fungal endosymbionts (Meister et al. 2006).

The low incidence of aphids in ryegrass is valuable information, because it indicates that this host can contribute less to aphid infestation in cereals than other grass pastures. On the other hand, black oats seems to be a suitable source for aphid spreading and colonization of cereal crops. The birdoat cherry aphid, R. padi, was found to be the most abundant aphid species. These findings agree with the results of Lau et al. (2009), who also found that $R$. padi as the main aphid species for conditions of south Brazil and low frequency of aphid species in ryegrass. Rhopalosiphum padi was the dominant aphid species until the third sampling and from the fourth on, $S$. avenae became the dominant species, because the later prefers the heads of the plants.

Similar variations were also found by Lau et al. (2009) with changes in predominance of $R$. padi by $S$. avenae from winter and spring months. Probably this occurred because of species feeding preferences, considering that $R$. padi is present during emergence and tillering plant stage and $S$. avenae is frequent during the reproductive stage (Salvadori \& Tonet 2001), which corresponded to the initial and final surveys, respectively.

The association of black oats + ryegrass reduced the global amount of aphids to approximately $50 \%$ of the aphid infestation found in the BO field. This finding reinforces the negative "ryegrass effect" on aphid populations.

Parasitism was greater in the $\mathrm{BO}+\mathrm{RG}$ field than in the BO field, in almost all surveys, although the aphid population was similar in both (Table III). In qualitative terms, another difference found was the incidence of the parasitoid $A$. colemani higher in $\mathrm{BO}+\mathrm{RG}$ than in $\mathrm{BO}$ fields (Table III). We assume that the difference is directly related to aphid species proportion between these two fields.

Species of Aphidius are considered biological control agents of aphids in Brazilian cereal crops (Starý et al. 2007). These species were imported by Brazilian research institutes in a classical biological control program during the last century, in 1970s and 1980s (Gassen \& Tambasco 1983). They became well adapted and succeeded as biological control agents of most cereal aphid species.

The parasitoid Diaeretiella rapae (Mclntosh, 1855) (Hymenopter, Braconidae) was not as abundant as Aphidius spp. and not a good control agent of cereal aphids, but it is considered to be an efficient parasitoid of many other aphid species (Le Ralec et al. 2011). In low aphid population density, D. rapae may be found parasitizing cereal aphids. However, even in this case, D. rapae is not a specialist parasitoid of cereal aphids, unlike Aphidius spp. (Rehman \& Powell 2010). 
The absence of Lysiphlebus testaceipes (Cresson, 1880) (Hymenoptera, Aphidiidae) is notable because it is considered one of the most common parasitoids of aphids in the tribe Aphidini (Aphis, Rhopalosiphum and Schizaphis) (Starý et al. 2007). The absence of specialized parasitoids of the Macrosiphini tribe is explained by the small population of $S$. avenae and $M$. dirhodum species. Two species of unidentified hyperparasitoids were found.

Pastures can be a source of aphids that infest cereal crops, but they can provide suitable environments for maintenance and multiplication of biological control agents (microhymenopteran parasitoids). It was observed that ryegrass was poorly infested by aphids. The mixture of heavily-infested plants (black oats) with poorly-infested plants (ryegrass) resulted in less aphids in comparison with a field cultivated with a single heavily-infested plant species. Also, the mixture seems favorable for increasing parasitism. Mixing two plant species is beneficial for natural aphid control in pastures.

In practical terms, the use of ryegrass as pasture, in mixed or isolate fields, is a good alternative because it is not favorable for increasing cereal aphid populations, but may favor natural parasitism in cereal fields.

\section{ACKNOWLEDGEMENTS}

The authors are grateful to Marcus Vinicius Sampaio Universidade Federal de Uberlândia for parasitoid identification; to José Henrique Souza da Silva, Universidade Federal de Santa Maria, for statistical analysis assistance and Rick Harder for English revision; to CAPES for the fellowships to the first three authors.

\section{REFERENCES}

Aguinaga, A. A. Q.; P. C. de F. Carvalho; I. Anghinoni; A. Pilau; A. J. Q. Aguinaga \& G. D. F. Gianluppi. 2008. Componentes morfológicos e produção de forragem de pastagem de aveia e azevém manejada em diferentes alturas. Revista Brasileira de Zootecnia 37: 1523-1530.

ARS-USDA, 2011. Forage and grazing lands biodiversity project - Pasture Diversity and Management. Pastures systems and watershed management research unity fact sheet. Available from: http://grazingguide.net/wpcontent/uploads/2011/05/Goslee_diversity_factsheet.pdf (accessed 6 October 2011).

Blackman, R. L. \& V. F. Eastop, 2000. Aphids on the World's Crops. An Identification and Information Guide. Second edition. New York: John Wiley \& Sons, 475 p.

Celis, V. R. de; D. Gassen; V. L. Valente \& A. K. de Oliveira. 1997. Longevity, fecundity and embryogenesis in Brazilian Aphids. Pesquisa Agropecuária Brasileira 32: 137-145.

Figueroa, C. C.; R. Loayza-Muro \& H. M. Niemeyer. 2002. Temporal variation of RAPD-PCR phenotype composition of the grain aphid Sitobion avenae (Hemiptera: Aphididae) on wheat: role of hydroxamic acids. Bulletin of Entomological Research 92: 25-33.
Fraser, L. H. \& J. P. Grimer. 1999. Aphid fitness in 13 grasses species: a test of plant defence theory. Canadian Journal of Botany 77: 1783-1789.

Gassen, D. N. \& F. J. Tambasco. 1983. Controle biológico dos pulgões do trigo no Brasil. Informe Agropecuário 9: 49-51

Givovich, A. \& H. M. Niemeyer. 1994. Effect of hydroxamic acids on feeding behaviour and performance of cereal aphids (Hemiptera: Aphididae) on wheat. European Journal of Entomology 91: 371-374.

Lau, D.; P. R. V. Da S. Pereira; J. R. Salvadori; J. Schons; G. Parizoto \& T. B. Mar. 2009. Ocorrência do Barley/Cereal yellow dwarf virus e seus vetores em cereais de inverno no Rio Grande do Sul, Santa Catarina, Paraná e Mato Grosso do Sul em 2008. Passo Fundo, Embrapa Trigo. Comunicado Técnico online, 256. Available at: http://www.cnpt.embrapa.br/ biblio/co/p_co256.htm (accessed 12 February 2012)

Le Ralec, A.; A. Ribulé; A. Barragan \& Y. Outreman. 2011. Host range limitation caused by incomplete host regulation in an aphid parasitoid. Journal of Insect Physiology 57: 363-371.

Lopes-da-Silva, M. \& L. G. E. Vieira. 2007. Analysis of Genetic Diversity of Metopolophium dirhodum (Walker) (Hemiptera, Aphididae) by RAPD markers. Revista Brasileira de Entomologia 51: 54-57.

Lopes-da-Silva, M. \& L. G. E. Vieira. 2010. Temporal genotypic diversity of Schizaphis graminum (Rondani, 1852) (Hemiptera: Aphididae) in a black oats (Avena strigosa) field. Brazilian Archives of Biology and Technology 53: 911-916.

Luczyszyn, V. C.\& P. Rossi Júnior. 2007. Composição bromatológica de pastagens de inverno submetidas a pastejo por ovinos, obtidas por fístulas esofágicas. Revista Acadêmica Ciências Agrárias e Ambientais 5: 345-351.

Meister, B.; J. Krauss; S. A. Härri; M. V. Schneider \& C. B. Müller. 2006. Fungal endosymbionts affect aphid population size by reduction of adult life span and fecundity. Basic and Applied Ecology 7: 244-252.

Muyheko, F. N.; A. T. Barrion \& Z. R. Khan. 2003. Grass diversity and the associated stemborers and natural enemies in different farming systems of Kenya. African Crop Science Conference Proceedings 6: 246253. Available at: http://www.acss.ws/Upload/XML/Research/57.pdf

Östmann, Ö. 2004. The relative effects of natural enemy abundance and alternative prey abundance on aphid predation rates. Biological Control 30: $281-287$.

Powell, G.; C. R. Tosh \& J. Hardie. 2006. Host plant selection by aphids: behavioral, evolutionary, and applied perspectives. Annual Review of Entomology 51: 309-330.

Rehman, A. \& W. Powell. 2010. Host selection behaviour of aphids parasitoids (Aphidiidae: Hymenoptera). Journal of Plant Breeding and Crop Science 2: 299-311.

Ronquin, J. C.; J. M. Pacheco \& C. C. Ronquin. 2004. Occurrence and parasitism of aphids (Hemiptera: Aphididae) on cultivars of irrigated oat (Avena spp.) in São Carlos, Brazil. Brazilian Archives of Biology and Technology 47: 163-169

Salvadori, J. R. \& G. E. L. Tonet. 2001. Manejo integrado dos pulgões de trigo. Passo Fundo, Embrapa Trigo, Documentos, 34.

Sanderson, M. A.; S. C. Goslee; K. J. Soder; R. H. Skinner; B. F. Tracy \& A. Deak. 2007. Plant species diversity, ecosystem function, and pasture management - A perspective. Canadian Journal of Plant Science 87: 479-487.

SAS. Statistical Analysis System - SAS. 2001. Statistical analysis system user's guide. Version 8.2. Cary: SAS Institute.

Starý, P.; M. V. Sampaio \& V. H. P. Bueno. 2007. Aphids parasitoids (Hymenoptera, Braconidae, Aphidinae) and their associations related to biological control in Brazil. Revista Brasileira de Entomologia 51: 107-118.

Vos, M. \& G. Jander. 2010. Volatile communication in plant-aphid interactions. Current Opinion in Plant Biology 13: 366-371. 